\title{
Heavy metal incorporation in foraminiferal calcite: results from multi-element enrichment culture experiments with Ammonia tepida
}

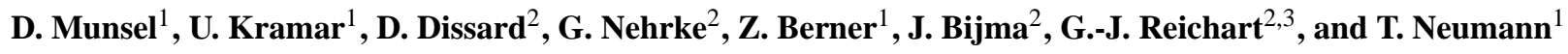 \\ ${ }^{1}$ Institute of Mineralogy and Geochemistry, Karlsruhe Institute of Technology, Karlsruhe, Germany \\ ${ }^{2}$ Alfred Wegener Institute for Polar und Marine Research, Biogeosciences, Bremerhaven, Germany \\ ${ }^{3}$ Faculty of Geosciences, Utrecht University, Utrecht, The Netherlands
}

Received: 20 January 2010 - Published in Biogeosciences Discuss.: 9 February 2010

Revised: 22 July 2010 - Accepted: 23 July 2010 - Published: 6 August 2010

\begin{abstract}
The incorporation of heavy metals into carbonate tests of the shallow water benthic foraminifer Ammonia tepida was investigated under controlled laboratory conditions. Temperature, salinity, and $\mathrm{pH}$ of the culture solutions were kept constant throughout the duration of this experiment, while trace metal concentrations were varied. Concentrations of $\mathrm{Ni}, \mathrm{Cu}$, and $\mathrm{Mn}$ were set 5-, 10-, and 20 times higher than levels found in natural North Sea water; for reference, a control experiment with pure filtered natural North Sea water was also analysed. The concentrations of $\mathrm{Cu}$ and $\mathrm{Ni}$ from newly grown chambers were determined by means of both $\mu$-synchrotron XRF and Laser Ablation Inductively Coupled Plasma Mass Spectroscopy (LA-ICP-MS). The results of both independent analytical techniques agreed within the analytical uncertainty. In general, the concentration of the analysed elements in the tests increased in line with their concentration in the culture solutions. Potential toxic and/or chemical competition effects might have resulted in the decreased incorporation of $\mathrm{Ni}$ and $\mathrm{Cu}$ into the calcite of the specimens exposed to the highest elemental concentrations. Mn incorporation exhibited large variability in the experiment with the 20-fold increased element concentrations, potentially due to antagonistic effects with $\mathrm{Cu}$. The partition coefficients of $\mathrm{Cu}$ and $\mathrm{Ni}$ were calculated to be $0.14 \pm 0.02$ and $1.0 \pm 0.5$, respectively, whereas the partition coefficient of Mn was estimated to be least 2.4. These partition coefficients now open the way for reconstructing past concentrations for these elements in sea water.
\end{abstract}

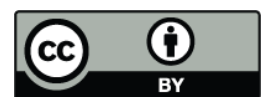

Correspondence to: D. Munsel (munsel@kit.edu)

\section{Introduction}

Foraminifera are unicellular eukaryotic microorganisms (Protozoa), found mainly in marine environments. Many species of Foraminifera, including Ammonia tepida, secrete shells, called "tests", which are composed of calcium carbonate. During shell construction, trace elements and stable isotopes from the sea water are incorporated into the calcareous tests. Because trace elements and stable isotopic ratios preserved in tests are often linked to ambient sea water conditions, geochemical data obtained from foraminiferal tests are widely used as so-called proxies in palaeo-climatology and oceanography (e.g. Boyle, 1981; Wefer et al., 1999; Lea, 2004). The appropriate application of these proxies, however, demands an accurate calibration between the actual sea water conditions and the chemistry of analysed foraminiferal tests.

According to Erez (2003), the actual process of foraminiferal test calcification begins with sea water uptake into vacuoles by endocytosis. Various pumps and channels subsequently increase $\mathrm{pH}$ and modify the elemental concentration in the vacuoles, which are then exocytosed into a "biomineralisation space" (Erez, 2003; de Nooijer et al., 2009). In the biomineralisation space, $\mathrm{CaCO}_{3}$ precipitates on an organic matrix, thereby defining the outline of a new test chamber (Hemleben et al., 1977). Trace elements present in this modified sea water precipitate along with the calcium carbonate and are incorporated into the shell. In addition to this biological control, physicochemical parameters such as $\mathrm{pH}$, temperature, salinity, and possibly pressure also influence the manner in which trace and minor elements are incorporated into calcium carbonate tests during shell precipitation.

Geochemical proxies are important tools and are commonly used to reconstruct past environmental conditions. For example, the use of oxygen isotopes in carbonates for

Published by Copernicus Publications on behalf of the European Geosciences Union. 
palaeothermometry, as suggested by Urey (1947), is still one of the most widely used proxies (e.g. Bemis et al., 1998; Lea, 2004). The proxy toolbox has increased enormously ever since. More recently, proxies based on $\mathrm{Mg} / \mathrm{Ca}$ ratios (e.g. Nürnberg et al., 1996; Lea et al., 1999) and Ca isotope ratios (e.g. Nägler et al., 2000) preserved in foraminiferal test carbonate have also been used to reconstruct sea water temperature. Other geochemical proxies useful in environmental reconstructions include B isotopes, which are used to determine $\mathrm{pH}$ changes in the ocean water (Sanyal et al., 2001; Yu et al., 2007), and Cd, which is a proxy for nutrient concentrations (Boyle, 1988; Rickaby and Elderfield, 1999; Martin and Lea, 1998).

Most calibrations of foraminiferal proxies are based on correlating average ambient conditions to the analyses of Foraminifera isolated from recent (i.e. core-top) sediment samples. Not only does this approach rely on the assumption that conditions have remained stable for a considerable length of time, but in order to eliminate secondary contaminations and overgrowths, complex cleaning protocols are usually implemented (e.g. Boyle and Keigwin, 1985/1986; Lea and Boyle, 1991; Martin and Lea, 2002). Moreover, under natural conditions environmental parameters often covary and thus are difficult to disentangle. To circumvent such complications, the use of controlled laboratory cultures was initially pioneered by Christoph Hemleben from Germany and Alan Bé from the USA. The first experiments focussing on quantifying foraminiferal elemental uptake of $\mathrm{Li}, \mathrm{Sr}, \mathrm{Mg}$, and $\mathrm{Na}$ were carried out by Delaney et al. (1985). Subsequent studies examined the uptake of Cd (Boyle, 1988; Mashiotta et al., 1997; Maréchal-Abram et al., 2004), Ba (Lea and Spero, 1992, 1994), U (Russel et al., 1994), and V (Hastings et al., 1996). One of the most recent studies published addressed $\mathrm{Cu}$ uptake (de Nooijer et al., 2007).

Biological productivity in the ocean is strongly impacted by trace metal distribution, which generally exhibits a nutrient-type depth profile within the water column. In particular, low concentrations of some first row transition metals are known to be essential for productivity. However, the distribution of trace metals in the ocean is affected by some geogenic processes (e.g. hydrothermal activity) and anthropogenic forces (e.g. pollution), as described below. Locally, geogenic processes such as hydrothermal activity can dramatically enrich the trace element composition of sea water for up to several kilometres from the active hydrothermal vent (German and von Damm, 2004). Although Foraminifera do not reside within hydrothermal vents, the overall increase of trace metal concentrations in the surrounding sea water due to hydrothermal activity will affect Foraminifera, particularly those living near the vent (e.g. Panieri, 2006). These hydrothermal effects are recorded in foraminiferal tests. For example, a field site which is known to be influenced by hydrothermal activity (DSDP Site 216, Ninety-east Ridge) yields specimens of benthic Foraminifera that are enriched in "hydrothermal" trace elements such as $\mathrm{Cu}, \mathrm{Co}$, and $\mathrm{Pb}$
(Meudt, unpublished data). Changes in redox conditions (e.g. Morford and Emerson, 1999) or anthropogenic pollution sources may also influence trace and minor element distribution in sea water and will be recorded by Foraminifera. Despite this, most pollution studies focus exclusively on bulk sediment analyses and/or foraminiferal distribution patterns (e.g. Alve, 1991, 1995; Vilela et al., 2004; BuzasStephens and Buzas, 2005; Carnahan et al., 2008), partly due to the fact that accurate distribution coefficients have not yet been determined for linking sea water chemistry with foraminiferal carbonates for many of the elements of interest. As polluted sediments are usually suboxic or anoxic due to enrichment in organic matter with high levels of sulphate reduction, heavy metals are often accumulated and bound to highly insoluble minerals such as sulphides. Hence, these metals are not bio-available and as a result, true pollution levels remain unknown. Heavy metals can only be remobilised in the sediment and diffused into the water with increasing oxygen levels. Analyses of foraminiferal calcite and partition coefficients of minor and trace metals could potentially reveal true trace metal availability. Thus foraminiferal calcite has the potential to become an excellent tool for monitoring marine pollution. However, except for $\mathrm{Cu}$ (de Nooijer et al., 2007), there are no experimental data available for first row transition metals such as $\mathrm{Mn}$ and Ni. To shed additional light on this subject, we conducted a multi-element experiment under controlled laboratory conditions for oxidising conditions using the shallow-water, benthic foraminifer Ammonia tepida.

\section{Methods}

\subsection{Sampling and culturing procedures}

Ammonia tepida (a shallow-water benthic foraminifer) is known to have a broad tolerance range for temperature and salinity, to withstand strong seasonal regimes, and to survive severe environmental conditions. Furthermore, Ammonia tepida are also easy to grow in the laboratory, where they can form new chambers and even reproduce (e.g. Bradshaw, 1957; Alve and Murray, 1999; Stouff et al., 1999; Pascual et al., 2002; le Cadre and Debenay, 2006; de Nooijer et al., 2007). Ammonia tepida was collected by sampling the upper $0.5 \mathrm{~cm}$ of sediment at low-tide in an intertidal mudflat of the Wadden Sea, part of the North Sea. The locality is situated near the Lower Saxony town of Dorum Neufeld, Germany (within Nationalpark Niedersächsisches Wattenmeer). In the laboratory, the sediment was sieved over a $125 \mu \mathrm{m}$ mesh sieve and was washed with filtered $(0.2 \mu \mathrm{m})$ sea water. Foraminifera were hand picked under a binocular microscope using a very fine brush and screened under a Zeiss Axiovert $200 \mathrm{M}$ inverted microscope for pseudopodial activity - which expresses vitality. Four hundred live individuals were transferred into and divided evenly among four separate sediment-free aquaria, each containing $1.25 \mathrm{~L}$ of culture 

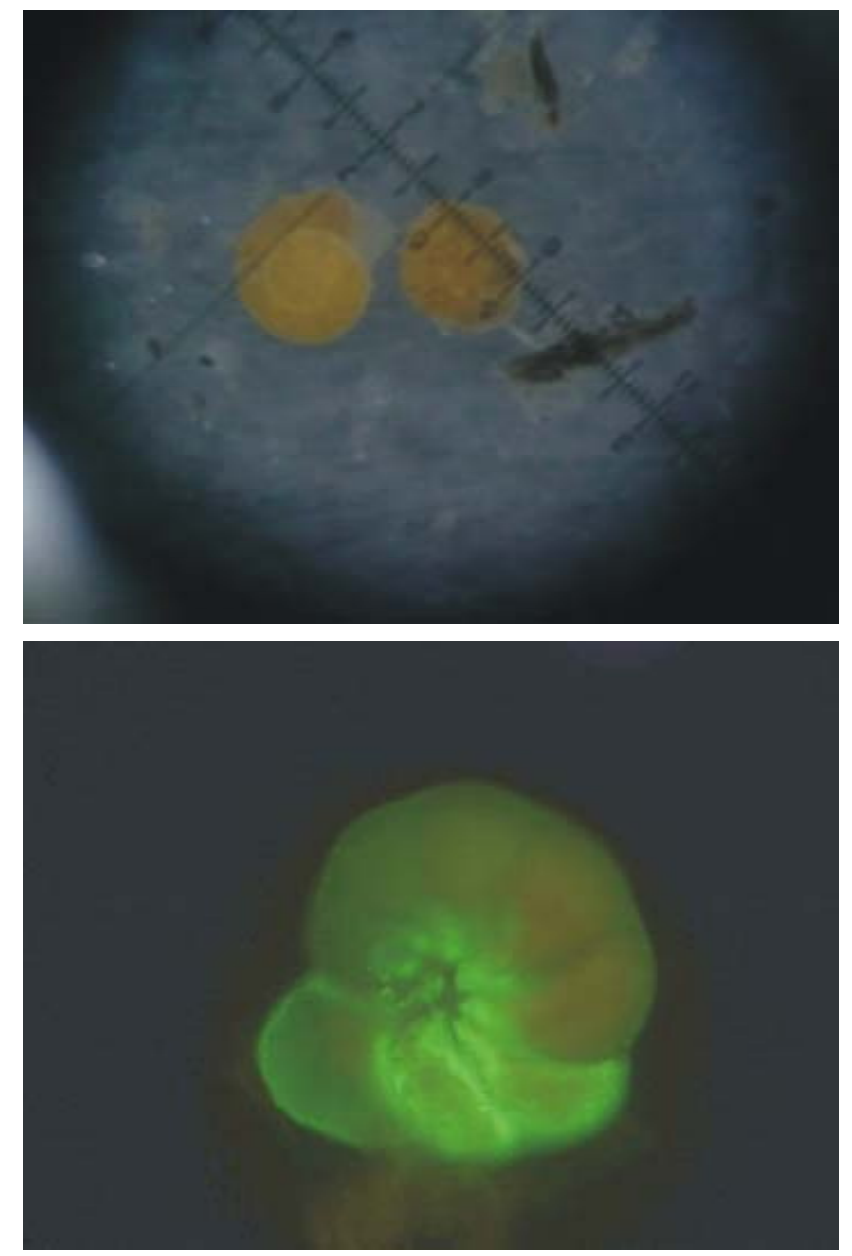

Fig. 1. Ammonia tepida under the light microscope (top), Ammonia tepida under UV light showing newly grown chambers marked with calcein (bottom).

solution. Before use, the aquaria were thoroughly cleaned with 10 vol.- $\% \mathrm{HNO}_{3}$ and rinsed with reverse osmosis water (ROW, conductivity $<0.067 \mu \mathrm{S} \mathrm{cm}^{-1}$ ).

A stock solution with defined concentrations of $\mathrm{Mn}$, $\mathrm{Co}, \mathrm{Ni}$, and $\mathrm{Cu}$ was prepared using ICP-standard solutions $\left(1000 \mu \mathrm{g} / \mathrm{mL}\right.$ in 5 vol.- $\% \mathrm{HNO}_{3}$ each) (Specpure, Alfa Aesar, Germany) and ROW water. Concentrations used in the experiments are listed in Table 1 . The $\mathrm{pH}$ of the stock solution was raised to $8.0 \pm 0.1$ with $1 \mathrm{M} \mathrm{NaOH}$ (p.a.) in order to match the $\mathrm{pH}$ of the natural sea water. Then, the stock solutions were added to the sea water (filtered with a $0.2 \mu \mathrm{m}$ membrane filter) until trace metal concentrations within the culture solutions reached approximately 5-, 10-, and 20 times that of the natural North Sea water. In addition, a reference batch without any additional trace metals was prepared. Finally, the culture solutions were filtered again using a $0.2 \mu \mathrm{m}$ membrane filter to avoid introducing possible inorganic precipitates in the aquaria. To mark newly grown chambers (Fig. 1), the fluorescent
Table 1. Mean concentrations of $\mathrm{Mn}, \mathrm{Ni}$, and $\mathrm{Cu}$ in the culture solutions. Reference $=$ North Sea water without added trace elements, 5-, 10- and 20-fold indicate 5-, 10-, and 20-fold concentrations of natural North Sea water.

\begin{tabular}{lccc}
\hline & $\begin{array}{c}\text { Manganese } \\
{[\mathrm{nmol} / \mathrm{L}]}\end{array}$ & $\begin{array}{c}\text { Nickel } \\
{[\mathrm{nmol} / \mathrm{L}]}\end{array}$ & $\begin{array}{c}\text { Copper } \\
{[\mathrm{nmol} / \mathrm{L}]}\end{array}$ \\
\hline Mean reference & $30 \pm 13$ & $48 \pm 14$ & $195 \pm 27$ \\
Mean 5-fold & $86 \pm 33$ & $231 \pm 70$ & $1012 \pm 233$ \\
Mean 10-fold & $113 \pm 45$ & $371 \pm 52$ & $1697 \pm 155$ \\
Mean 20-fold & $209 \pm 56$ & $649 \pm 105$ & $3290 \pm 263$ \\
\hline
\end{tabular}

label calcein (bis[N,N-bis(carboxymethyl)aminomethyl]fluorescein) (Sigma-Aldrich) was added to the sea water at a concentration of $5 \mathrm{mg} / \mathrm{L}$ before it was mixed with the stock solution (Bernhard et al., 2004).

Foraminiferal cultures were performed without sediments or any other substrate to avoid artefacts, which could be induced by adding sediments (e.g. pore water chemistry). Consequently, only the water chemistry had to be controlled and monitored. The four aquaria were covered with a fibre-glass plate, to minimise evaporation, and then they were placed in a temperature controlled cabinet. Salinity ( $24 \mathrm{psu}), \mathrm{pH}$ $(8.0 \pm 0.1)$ and temperature $\left(14.5^{\circ} \mathrm{C} \pm 0.2^{\circ} \mathrm{C}\right)$ were monitored every other day and were stable over the course of the experiments (Fig. 3). To prevent bacterial build-up, the culture solutions were changed every 4 weeks. Vitality of specimens was checked bi-weekly: Ten specimens were randomly selected from each tank and screened for pseudopodial activity with the aid of an inverted microscope. Food, which consisted of approximately $5 \mathrm{mg}$ of a mixture of air dried algae (Phaeodactylum triconortum, Dunaliella salina and Isochrisis galbana), was added to the aquaria at the beginning of the experiment and every time food was no longer visible (6 and 8 weeks after the start of the experiment). The total duration of this experiment was 82 days.

The elemental composition of the culture solutions were measured weekly using High Resolution Inductively Coupled Plasma Mass Spectroscopy (HR-ICP-MS, type Axiom from VG Elemental). The analyses showed that the target trace metal concentrations remained within an acceptable range throughout the experiment (Table 1). Accuracy of the analyses was verified by measuring the certified water reference sample CRM-TMWD (High Purity Standards, USA) in every analytical batch.

At the end of the experiment, all specimens were screened for pseudopodial activity before the tests were cleaned of organic material during which the specimens were soaked in a solution of 6-8 vol.- $\% \mathrm{NaOCl}$ (Merck), twice, for two to three hours at a time (Mashiotta et al., 1999; Pak et al., 2004). Finally, the tests were rinsed four times with ROW water and allowed to dry thoroughly before being analysed. 


\subsection{Analytics}

\subsection{1 $\mu$-synchrotron XRF}

Using a liquid glue (Tesa, Beiersdorfer, Germany), two rows (each consisting of five individuals) of tests were affixed with their spiral side onto a $3 \mu \mathrm{m}$ mylar film that was attached to plastic slide mounts. The glue as well as the mylar film were tested for their trace element constituents before use. The abundances of all elements of interest were clearly below the detection limits for $\mu$-synchrotron X-Ray Fluorescence Spectroscopy (XRF) determinations. Newly grown chambers as well as some old chambers were analysed by $\mu$-synchrotron XRF at the FLUO-beamline of ANKA synchrotron facility (Karlsruhe) and at HASYLAB beamline L (DESY, Hamburg) where confocal $\mu$-XRF measurements were carried out (for details about the confocal measurements, see Kramar et al., 2010). Using an excitation energy of $12.5 \mathrm{keV}$, and focussing refractive lenses to a point size of $2 \times 5 \mu \mathrm{m}$, the chambers were analysed by line scans, averaging five points per line in newly grown chambers and three points per line in old chambers. In unfiltered sample spectra, the Ni-K lines were strongly overlain by the intense Ca sum-peak due to the calcium carbonate matrix of the investigated foraminiferal tests. To reduce this interference, a $20 \mu \mathrm{m}$ secondary beam aluminium filter was mounted in front of the fluorescence detector. Due to low trace element concentrations in the sub $\mu \mathrm{g} / \mathrm{g}$ and lower $\mu \mathrm{g} / \mathrm{g}$ range, long measuring times $(500 \mathrm{~s})$ were necessary at each point. Trace element contents in the tests were quantified by fundamental parameters using PyMCA 4.2.2 (Solé et al., 2007). The fundamental parameter calculations were recalibrated for trace element calibration purposes by using a pressed calcite pellet (containing $756 \mu \mathrm{g} / \mathrm{g} \mathrm{Cr}$ and $727 \mu \mathrm{g} / \mathrm{g}$ As) and the MPI-DING reference glass StHS6/80-G standard (Max-Planck-Institut für Chemie, Germany) (Jochum et al., 2000) as primary standards. Geometry effects caused by the uneven shape of the tests were corrected by calculating the absorption of the incoming beam from the count rate of the primary monitor (in front of the sample) and the secondary monitor (behind the sample). Because the calcium concentration ( $40 \mathrm{wt} \%)$ is constant in calcite, the average path length of the outgoing beam could be calculated using $\mathrm{Ca}$ as internal standard (Kramar et al., 2010). Replicate measurements of the same spots lay within 5\% relatively, while errors resulting from the path length calculations through the chamber walls are estimated to $10-20 \%$ relatively. These effects are discussed in detail in Kramar et al. (2010).

\subsubsection{LA-ICP-MS}

The non-destructive nature of $\mu$-synchrotron XRF allowed Laser Ablation Inductively Coupled Plasma Mass Spectroscopy (LA-ICP-MS) measurements of the same chambers. For these measurements, specimens were fixed on a doublesided adhesive tape and mounted on plastic stubs.
The analyses were conducted at Utrecht University (Department of Earth Sciences) by means of an excimer laser (Lambda Physik, Germany) equipped with GeoLas 200Q optics at a wavelength of $193 \mathrm{~nm}$. The ablation was conducted in a helium atmosphere. Pulse rate was adjusted to six pulses per second with an energy density of $1 \mathrm{~J} / \mathrm{cm}^{2}$ at the surface of the sample. The laser beam was set to a diameter of $80 \mu \mathrm{m}$. The ablated material was analysed with a quadrupole ICPMS (Micromass Platform). A collision and reaction cell was used to minimise spectral interferences on the minor isotopes of Ca (Mason and Kraan, 2002). Calcium was used as an internal standard, via the ${ }^{44} \mathrm{Ca}$ isotope, with simultaneous monitoring of ${ }^{42} \mathrm{Ca}$ and ${ }^{43} \mathrm{Ca}$. For calibration of trace element contents, the NIST SRM 610 glass standard (National Institute of Science and Technology, USA) (Pearce et al., 1997) and an in-house matrix-matched calcite standard (GJR) were applied. Concentrations of $\mathrm{Cu}$ and $\mathrm{Ni}$ were calculated using the ${ }^{63} \mathrm{Cu}$ and ${ }^{60} \mathrm{Ni}$ isotopes, to correct for their natural isotopic abundances. Mn was quantified using its only natural isotope, ${ }^{55} \mathrm{Mn}$. Internal relative precision of $\mathrm{Mn}, \mathrm{Ni}$, and $\mathrm{Cu}$ was better than $4.5 \%, 4.7 \%$, and $4.8 \%$, respectively.

\subsection{Calculation of partition coefficients}

Partition coefficients were calculated using the resulting trace element (TE) and calcium concentrations according to the following expression:

$D_{\mathrm{TE}}=(\mathrm{TE} / \mathrm{Ca})_{\text {calcite }} /(\mathrm{TE} / \mathrm{Ca})_{\text {sea water }}$.

$D_{\mathrm{TE}}$ were calculated using the medians of each set of concentration measurements. Because the analytical data did not show a Gaussian distribution, the medians are a more reliable and robust parameter (e.g. Hoaglin et al., 1983; Zhou, 1987) than the means. Subsequently, the mean of the medians of the reference, 5-, and 10-fold concentrations was calculated as the distribution coefficient. The error envelope was calculated using the standard error of the mean (e.g. Howarth, 1983). The results of the 20 -fold concentration solution experiment were not included in the calculations. For more details see Sect. 3.4 and the Discussion.

\section{Results}

\subsection{Culture media}

Continuous monitoring of the culture solution revealed that the trace element concentrations corresponded well to the targeted concentrations. The elements of the stock solution therefore did not precipitate or absorb when mixed with the culture solution, nor were they consumed to an appreciable degree over the course of the experiment (Fig. 2 and Table 1). 
Table 2. Chamber addition of the cultured foraminifera.

\begin{tabular}{|c|c|c|c|c|c|c|c|c|c|}
\hline \multirow[t]{2}{*}{ Aquarium } & \multirow{2}{*}{$\begin{array}{c}\text { No. of } \\
\text { individuals } \\
\text { (start of } \\
\text { experiment) }\end{array}$} & \multirow{2}{*}{$\begin{array}{c}\text { Living } \\
\text { individuals } \\
\text { (end of } \\
\text { experiment) } \\
{[\%]}\end{array}$} & \multicolumn{5}{|c|}{ No. of chambers formed } & \multirow{2}{*}{$\begin{array}{l}\text { Individuals } \\
\text { that } \\
\text { formed } \\
\text { chambers } \\
{[\%]}\end{array}$} & \multirow{2}{*}{$\begin{array}{l}\text { No. of } \\
\text { offsprings }\end{array}$} \\
\hline & & & 1 & 2 & 3 & 4 & 5 & & \\
\hline Reference & 100 & 98 & 10 & 14 & 12 & 9 & 2 & $47 \pm 7$ & 0 \\
\hline 5-fold NSW & $100^{*}$ & 97 & 22 & 19 & 8 & 0 & 0 & $53 \pm 7$ & 0 \\
\hline 10-fold NSW & 100 & 94 & 22 & 16 & 0 & 0 & 0 & $41 \pm 6$ & 1 \\
\hline 20-fold NSW & 100 & 93 & 20 & 9 & 0 & 0 & 0 & $29 \pm 5$ & 0 \\
\hline
\end{tabular}

* Seven individuals were lost during water changes; NSW = North Sea water.
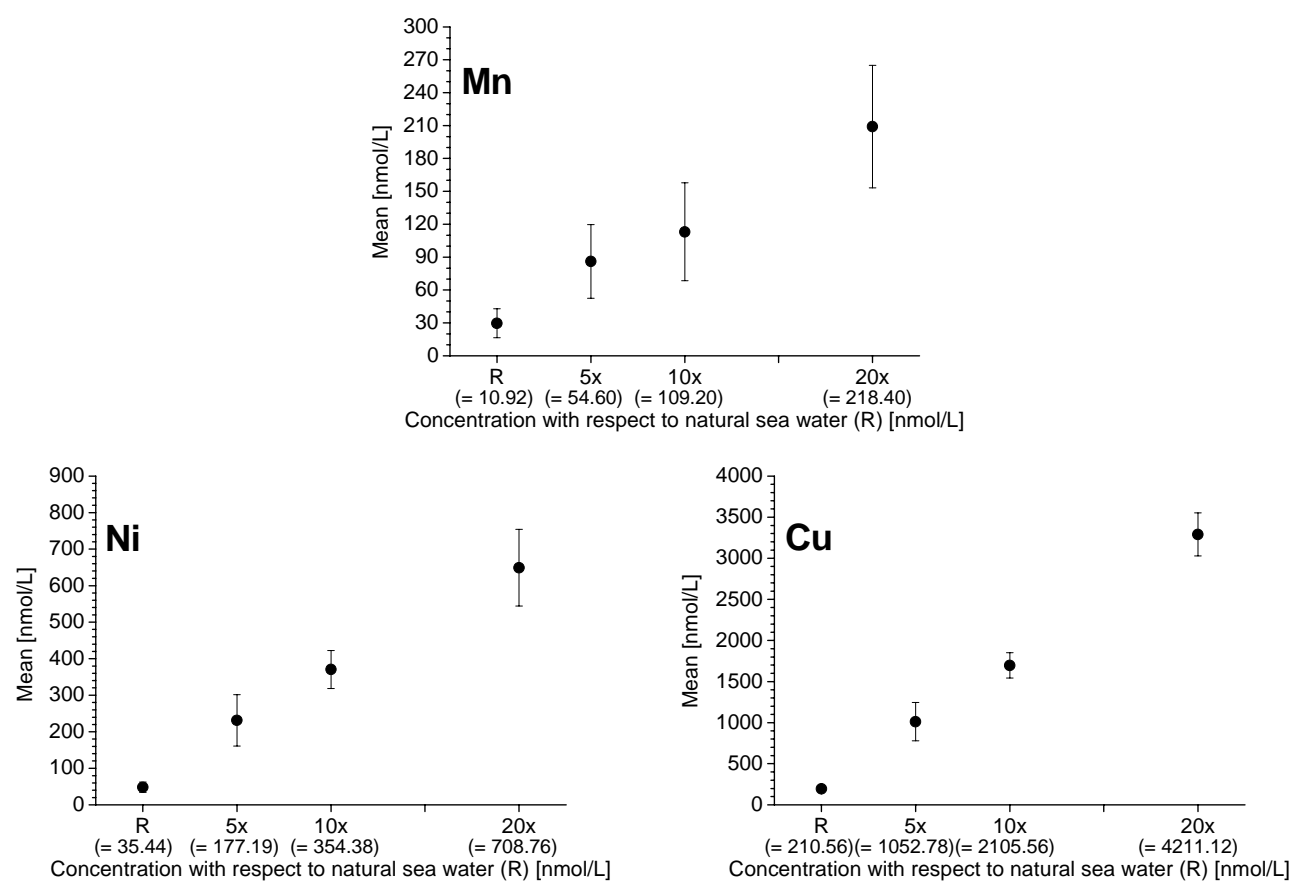

Fig. 2. Variation in the concentration [nmol/L] of $\mathrm{Mn}$ (top), $\mathrm{Ni}$ (lower left) and $\mathrm{Cu}$ (lower right) of each culture solution during the experiment; $\mathrm{R}=$ reference (natural sea water). Values in parentheses are theoretical values calculated on basis of pure sea water measurements performed before the experiment.

\subsection{Newly grown foraminiferal calcite}

Nearly all specimens, $95.5 \%$ on average, survived the culture period of 82 days - exact values for each experiment are listed in Table 2. In one of the aquaria (10-fold concentration), reproduction occurred, but only one juvenile foraminifer was recovered after termination of the experiments. Seven individuals of the 5-fold concentration experiment were lost during water changes. New chambers formed in all experiments. For the reference experiment, $47 \%$ of the specimens formed at least one new chamber. In the 5-, 10and 20 -fold concentration experiments, $53 \%, 41 \%$, and $29 \%$ of the individuals formed at least one new chamber, respectively (Table 2 and Fig. 4).

\subsection{Comparison of the applied analytical techniques}

The precision of measurements for Co analyses was low as the measured concentrations were too close to or under the detection limit for both analytical methods. For the other elements (especially $\mathrm{Cu}$ and $\mathrm{Ni}$ ) the LA-ICP-MS measurements display a similar range to that measured by $\mu$-synchrotron XRF.

Although the analyses show a wide range of variability in trace metal uptake among individual specimens, clear trends are observed for $\mathrm{Cu}$ and Ni. Similar variability between specimens grown under identical conditions was observed for both $\mathrm{Mg}$ and $\mathrm{Sr}$ (e.g. Reichart et al., 2003; DueñasBohórquez et al., 2009; Dissard et al., 2010a,b) and seems 

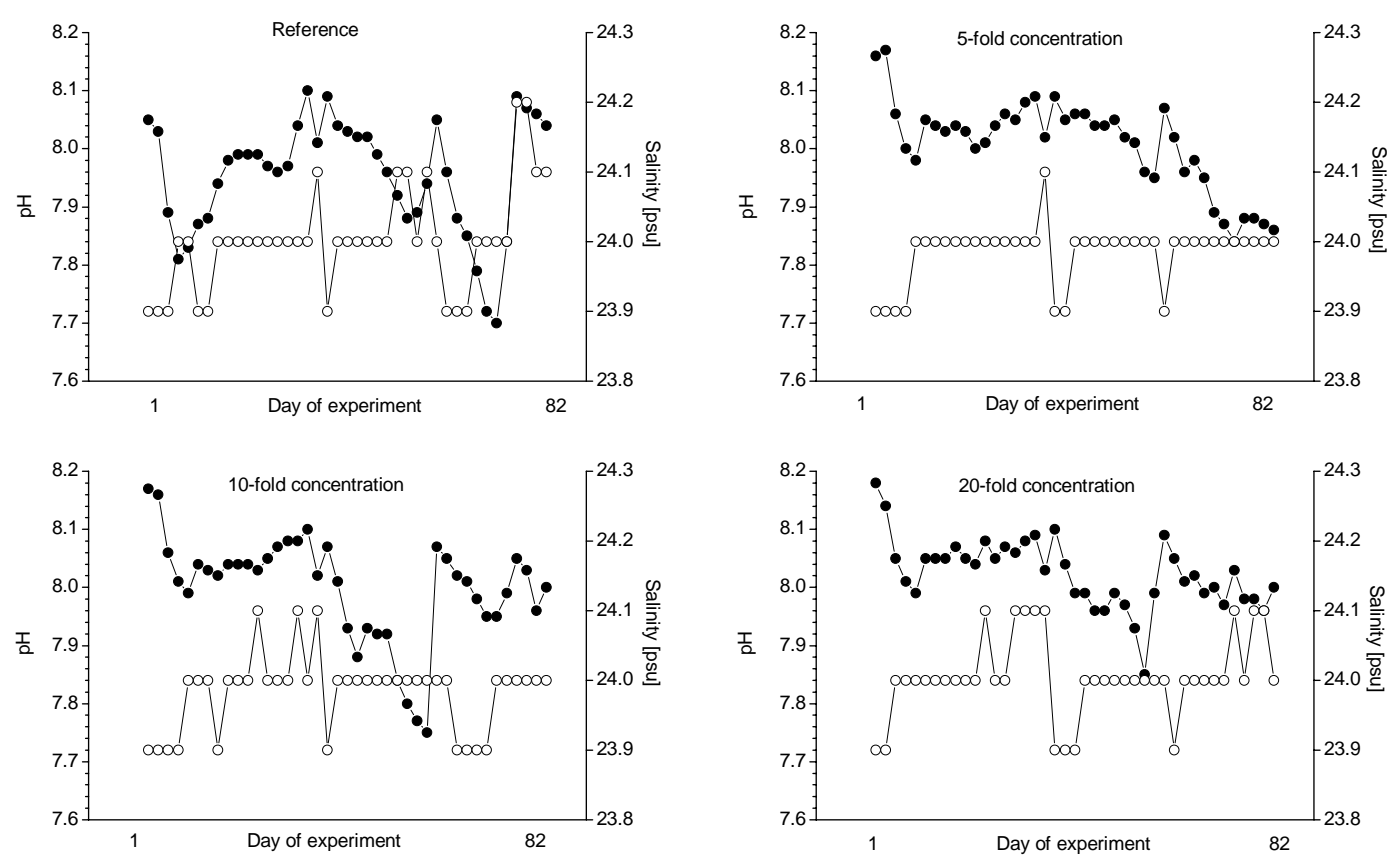

Fig. 3. Salinity $[\mathrm{psu}](\mathrm{o})$ and $\mathrm{pH}(\bullet)$ monitoring of each culture solution throughout the 82 days of the experiment.

to reflect differences in elemental uptake between individuals rather than analytical uncertainties. This is confirmed by the fact that irrespective of the analytical technique used (LA-ICP-MS or $\mu$-synchrotron XRF), the concentrations of $\mathrm{Ni}$ and $\mathrm{Cu}$ in the calcite increase with increasing concentrations in the sea water (Table 1, Figs. 2 and 5), except for the tests grown at the highest concentration (20-fold).

\subsection{Partition coefficients}

Partition coefficients for $\mathrm{Ni}$ and $\mathrm{Cu}$ were deduced from molar foraminiferal test $\mathrm{Ni} / \mathrm{Ca}$ and $\mathrm{Cu} / \mathrm{Ca}$ ratios and the corresponding sea water values (Fig. 5). The solid lines in Fig. 5 represent calculated partition values, based on the calculated medians for the different experiments. The dotted lines show the highest upper and the lowest lower quartile values, which display the area of uncertainty.

As shown in Fig. 5, $D_{\mathrm{Cu}}$ ranges between 0.08 and 0.25 , and $D_{\mathrm{Ni}}$ ranges between 0.4 and 2.0. The scatter in the Mn data (Fig. 6) allows only an estimate of $D_{\mathrm{Mn}}$, being at least 2.4.

A systematic decline in the concentration of $\mathrm{Ni}$ and $\mathrm{Cu}$ incorporated in newly grown chambers was observed in the specimens from the 20-fold experiment in comparison to those cultured in the 10-fold solution (Fig. 5). This suggests that an additional process may have affected the incorporation of $\mathrm{Ni}$ and $\mathrm{Cu}$ at high concentrations (see Sect. 4.2). For this reason the partition coefficients were calculated without the data of the 20 -fold concentration experiment. The decrease in values was quantified by both the $\mu$-synchrotron $\mathrm{XRF}$ and the LA-ICP-MS analytical techniques.

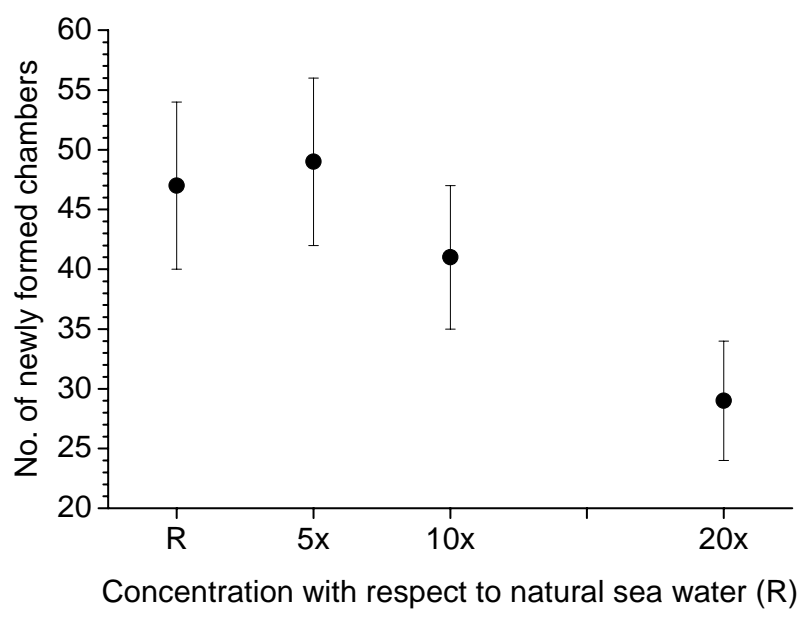

Fig. 4. Total number of newly formed chambers plotted against concentration of culture solutions.

\section{Discussion}

\subsection{Considerations of experimental uncertainties}

The element concentrations in the culture solutions were remarkably stable, and values for both $\mathrm{Cu}$ and $\mathrm{Ni}$ concentrations show only minor scatter (Fig. 2 and Table 1). The variability observed in $\mathrm{Mn}$ is somewhat more significant, possibly because $\mathrm{Mn}$ readily forms oxides and hydroxides under oxic conditions (e.g. Middelburg and de Lange, 1988; Heiser et al., 2001). 

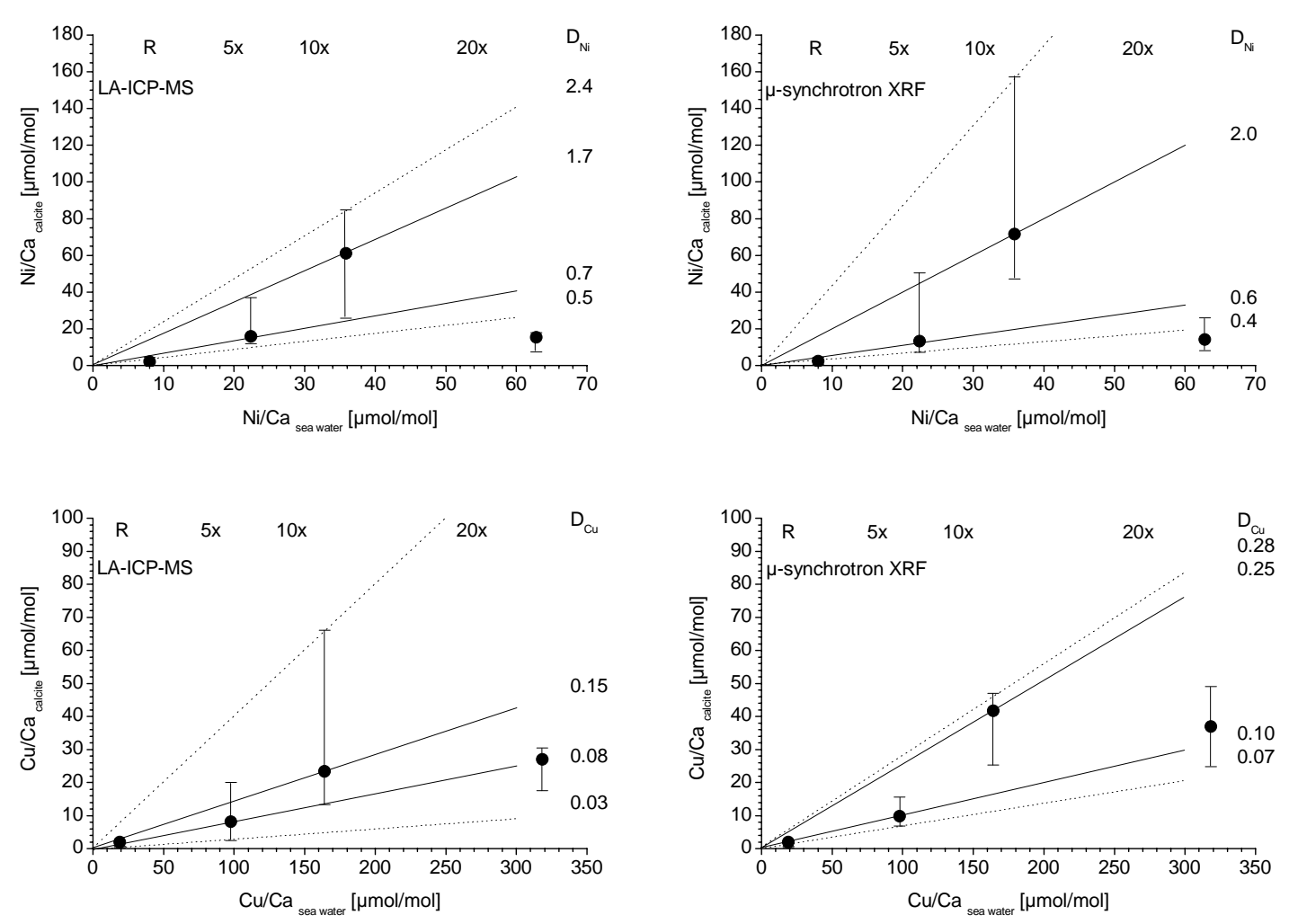

Fig. 5. Calculated partition coefficients of $\mathrm{Ni}$ (upper two graphs) and $\mathrm{Cu}$ (lower two graphs) - based on LA-ICP-MS (left side) and $\mu$ synchrotron XRF (right side) measurements. The black filled circles $(\bullet)$ display the median value of the observed concentration ratios, the short horizontal lines (-) symbolise the $25 \%$ (lower line) and the $75 \%$ quartile (upper line). Solid lines show the range in median values for reference, 5-, and 10-fold concentration solutions; dotted lines display the upper and/or lower quartiles and mark the area of uncertainty.
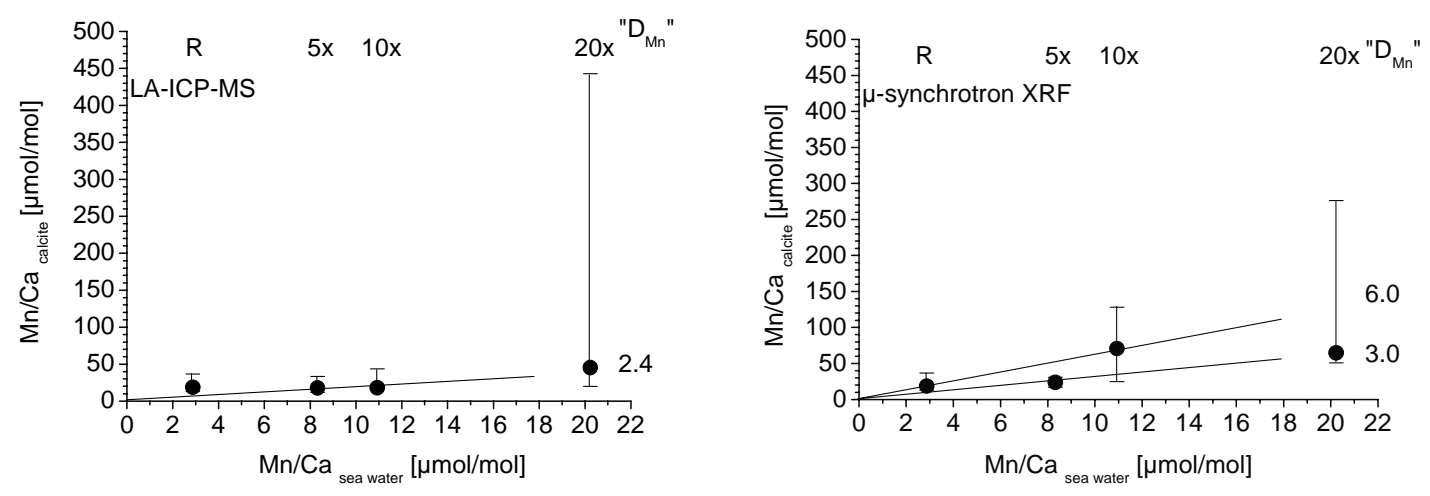

Fig. 6. Estimates for the partition coefficients for Mn. Explanation of the symbols as in Fig 5.

Calcein binds to $\mathrm{Ca}$ as calcium carbonate is precipitated and is therefore incorporated into the mineralised structure (Bernhard et al., 2004). Although Lu and Allen (2002) report that $\mathrm{Cu}$ incorporation competes with $\mathrm{Mg}$ and $\mathrm{Ca}$ (its incorporation is reduced at increased $\mathrm{Ca}$ and/or $\mathrm{Mg}$ concentrations), Hintz et al. (2004) as well as Dissard et al. (2009) suggest that the (trace) element incorporation is not affected by the use of calcein. De Nooijer et al. (2007) also report that $\mathrm{Cu}$ binding to calcein is negligible. Hintz et al. (2004) argue that measured $\mathrm{Mg} / \mathrm{Ca}$ ratios in calcein labelled chambers were of the same magnitude as the ratios in unlabelled chambers. Similarly, Dissard et al. (2009) showed that calcein does not affect the incorporation of the elements $\mathrm{Mg}$ and $\mathrm{Sr}$ into foraminiferal calcite. Our measured $\mathrm{Mg} / \mathrm{Ca}$ ratios (not shown here) confirm this assumption.

As shown in Table 2, $41( \pm 6) \%$ of the foraminifers in the culture solutions grew at least one chamber, with the exception of the 20-fold solutions in which a lower percentage 
$(29 \pm 5 \%)$ added new chambers. No malformed chambers were observed during this experiment and nearly all individuals (95.5\%, Table 2) survived. In pollution studies, malformed chambers of foraminiferal tests are often considered indicative of great stress, for instance resulting from pollution by heavy metals (e.g. Alve, 1991; Yanko et al., 1998). Given that the chamber formation and survivor rate were still quite high, and the absence of malformed chambers, we assume that the experimental conditions were quite acceptable for Ammonia tepida. The low reproduction rates observed here may indicate that the overall conditions for the experiment were perhaps suboptimal for this species, but that is not necessarily the case. Microcosm experiments similar to those conducted by Havach et al. (2001) or Hintz et al. (2006) might have improved the overall survival and chamber formation rate, but would have also introduced other complications, particularly with regard to keeping the trace element concentrations constant.

Data remains inconclusive for some of the individual tests. This can primarily be explained by the fact that some chambers had very thin walls, which resulted in a reduction of the ablation time as less material was available to ablate and thus yielded poor signal statistics. Unfortunately, the limited size (size of newly formed chambers $<100 \mu \mathrm{m}$ ) of the newly added chambers prevented multiple analyses on a single chamber with LA-ICP-MS.

\subsection{Biological effects and influences}

The elements $\mathrm{Mn}, \mathrm{Ni}$, and $\mathrm{Cu}$ usually are present only at very low levels in sea water (e.g. Table 1). Of these, Mn occurs at lowest concentration in the North Sea water we used (see Table 1). All of these metals seem to be essential for the growth of primary producers and exhibit a nutrient-type distribution or a hybrid distribution (a combination of nutrienttype and scavenged-type distributions) in the oceans (Jones and Murray, 1984; Bruland and Lohan, 2004; Morel et al., 2004). Although well below concentrations generally considered toxic (e.g. Hunt et al., 2002; Croteau and Luoma, 2009), the severe drop in trace element concentrations in the tests grown in the 20-fold concentration tank (shown in Fig. 5) suggests that a biological mechanism is involved. The trace metals considered are all somehow involved in different enzymatic activities (Nelson and Donkin, 1985). Whereas a deficiency in these elements may lead to limited productivity, conversely, an excess of these elements may inhibit growth (Sunda, 1988-1989; Bruland et al., 1991). The lower number of chambers added in these experiments, particularly in the 20 -fold experiment (see Table 2 for details), seems to point in this direction as well. As a consequence of using a multielement mixture in the culture medium, it is possible that one (or more) of the added elements reached its toxic (although non-lethal) level with respect to Ammonia tepida.
$\mathrm{Ni}$ is known to be a highly toxic element even though it is very common in nature as a cofactor in the urease enzyme that hydrolyses urea, which is an important source of nitrogen in the oceans (Oliveira and Anita, 1986). Ni also serves as a cofactor in various other enzymes. Accordingly, Ni must be considered an important prerequisite for diatom growth (Syrett and Peplinska, 1988). Dyhrman and Anderson (2003) made similar observations with respect to $\mathrm{Ni}$ for some dinoflagellate species. Apart from this, Ni is also essential for microbiologically-induced calcite precipitation. Culture experiments with Escherichia coli reveal that adding $5 \mu \mathrm{M} \mathrm{Ni}$ enhances calcite precipitation considerably, whereas an addition of more than $100 \mu \mathrm{M}$ Ni will inhibit calcite precipitation (Bachmeier et al., 2002). Similar observations were made during this study. The chamber growth rate for specimens cultured in the 5-fold solution increased $6 \%$ over those cultured in the reference solution, whereas the rate decreased $6 \%$ below reference values in the 10 -fold solution; the rate decreased even more dramatically in the highest concentrated solution (Table 2 and Fig. 4). Results of Mann et al. (2002) indicate that $\mathrm{Cu}$ may be toxic and/or harmful to various phytoplankton species. In this particular case, however, it is rather unlikely that $\mathrm{Cu}$ inhibited shell development as de Nooijer et al. (2007) used significantly higher concentrations in their experiments (in that study, up to $17.8 \mu \mathrm{mol}$ of $\mathrm{Cu}$ was applied, which is equivalent to a 100 -fold concentration increase compared to the sea water we used in our study) and still achieved new chamber growth. However, interactions between trace metals, in which one element becomes toxic due to the limitation of another, have been observed. For example, Egleston and Morel (2008) reported that Ni became toxic due to the limitation of $\mathrm{Zn}$, resulting in toxicity to diatoms. Bruland et al. (1991) found that synergistic and antagonistic interactions between $\mathrm{Cu}$ and potential biolimiting metals, such as $\mathrm{Fe}, \mathrm{Mn}$, and $\mathrm{Zn}$, might have large effects on the production of marine biota. Such an antagonistic effect, also described by Sunda and Huntsman (1998b) for $\mathrm{Cu}$ and $\mathrm{Mn}$, seems to be present in our experiments as well. Figures 5 and 6 show that tests from the 20 -fold concentration experiments might display such an antagonism between $\mathrm{Cu}$ (as well as $\mathrm{Ni}$ ) and $\mathrm{Mn}$.

The fact that high concentrations of $\mathrm{Ni}$ and $\mathrm{Cu}$ may harm marine life could potentially trigger a cellular expulsion or blocking mechanism in order to prevent Foraminifera from incorporating these metals in proportion to their sea water concentrations. It is also known that toxic metals such as $\mathrm{Cu}, \mathrm{Cd}, \mathrm{Ni}$, or $\mathrm{Zn}$ inhibit $\mathrm{Mn}$ uptake, when $\mathrm{Mn}$ is present in low concentrations (e.g. Sunda and Huntsman, 1998a,b). In terms of chemical competition, Mn binding is blocked by (toxic) trace metals, which bind to the receptor sites on transport-specialised membrane proteins designed for the acquisition of nutrients (Sunda and Huntsman, 1983, 1996, 1998a). Once the toxins are bound, the membrane nutrientmetal uptake system cannot distinguish between nutrient and toxicant. 


\subsection{Partition coefficients}

The partition coefficients for $\mathrm{Cu}\left(D_{\mathrm{Cu}}\right)$ and $\mathrm{Ni}\left(D_{\mathrm{Ni}}\right)$ were calculated based on data measured with two different analytical methods, $\mu$-synchrotron XRF and LA-ICP-MS. According to both methods, $D_{\mathrm{Cu}}$ lies between 0.08 and 0.25 . Based on the $\mu$-synchrotron XRF measurements, $D_{\mathrm{Cu}}$ was found to be $0.16 \pm 0.04$, whereas a value of $0.12 \pm 0.02$ was determined with the LA-ICP-MS. Hence, the average $D_{\mathrm{Cu}}$ is $0.14 \pm 0.02$. This is slightly lower than - but in the same range as - the previously determined partition coefficient for $\mathrm{Cu}$ by de Nooijer et al. (2007: $0.25 \pm 0.15$ using LAICP-MS as well). Although de Nooijer et al. (2007) used the same LA-ICP-MS configuration as the current study, our $\mu$-synchrotron measurements compare better with their findings.

A broader range of values was observed with respect to Ni. $D_{\mathrm{Ni}}$ varied between 0.4 and 2.0 (average $D_{\mathrm{Ni}}=1.0 \pm 0.5$ ) and between 0.5 and 1.7 (average $D_{\mathrm{Ni}}=1.0 \pm 0.4$ ) using $\mu$ synchrotron XRF and LA-ICP-MS, respectively. Again, results from both analytical techniques are found to agree. Combining $D_{\mathrm{Ni}}$ from both analytical methods gives a value of $1.0 \pm 0.5$.

Because both analytical techniques yield very similar results, it is valid to calculate a total $D$ for $\mathrm{Ni}$ and $\mathrm{Cu}$ by taking the mean of the individually calculated partition coefficients from both methods. In this way, possible systematic errors of both analytical techniques are reduced and averaged out.

\section{Conclusions}

The present study, based on analysis of calcareous tests of the benthic foraminifer Ammonia tepida, was conducted to determine partition coefficients for trace elements $(\mathrm{Cu}, \mathrm{Ni}$, and $\mathrm{Mn}$ ) that are typically associated with changing redox conditions, hydrothermal activity, and environmental pollution. The conditions in multi-element culture experiments better mimic natural environmental conditions than those commonly used in single element experiments. If results from single element experiments are to be applied to the natural environment, then potentially quenching effects must be taken into account, as demonstrated in this experiment by the decreased uptake of both $\mathrm{Ni}$ and $\mathrm{Cu}$ when those metals are present in higher concentrations. Ignoring inter-element interference might result in artificially high toxic or subtoxic concentrations of certain elements and, thus leading to inaccurate reconstructions.

The partition coefficients for $\mathrm{Cu}$ and $\mathrm{Ni}$ are calculated to be $0.14 \pm 0.02$ and $1.0 \pm 0.5$, respectively. These coefficients can now be used in environmental and palaeo studies based on fossil Foraminifera to more accurately determine the $\mathrm{Cu} / \mathrm{Ca}$ and $\mathrm{Ni} / \mathrm{Ca}$ ratios of sea water.
This study also reveals that in addition to LA-ICP-MS, $\mu$ synchrotron XRF is a very useful method to assess the concentration of trace elements in calcareous foraminiferal tests, with the additional advantage that the sample material is not destroyed and, therefore, at the same measuring point analytical conditions can be optimised.

Acknowledgements. The authors gratefully acknowledge B. Müller and A. Benthien (both AWI Bremerhaven) for assistance in the laboratory. We thank C. Haug (KIT) for her help with the preparation of the stock solutions and we are grateful to C. Mößner (KIT) for her invaluable help with the continuous ICP-MS measurements of the culture solutions. Special thanks go to R. Simon (ANKA) and $\mathrm{K}$. Appel (HASYLAB) for their assistance with the $\mu$-synchrotron measurements. ANKA and HASYLAB are acknowledged for providing beam time. We thank the two anonymous reviewers for their helpful comments that resulted in a more complete final manuscript. L. Fay is acknowledged for her help in editing this manuscript. This work was partly supported by the German Research Foundation (DFG) under Grant No. STU 169-34/2, Grant No. BI 432/4-2 ("PaleoSalt"), and Grant No. BI 432/6-2 ("BioCalc"), as well as by the European Science Foundation (ESF) under the EUROCORES Programmes EuroCLIMATE and EuroMinScI, respectively, through Contract No. ERAS-CT-2003-980409 of the European Commission, DG Research, FP6.

Edited by: A. Shemesh

\section{References}

Alve, E.: Benthic foraminifera in sediment cores reflecting heavymetal pollution in Sørfjord, western Norway, J. Foramin. Res., 21, 1-19, 1991.

Alve, E.: Benthic foraminiferal responses to estuarine pollution - a review, J. Foramin. Res., 25, 190-201, 1995.

Alve, E. and Murray, J. W.: Marginal marine environments of the Skagerrak and Kattegat: A baseline study of living (stained) benthic foraminiferal ecology, Palaeogeogr. Palaeoclim. Palaeoecol., 146, 171-193, 1999.

Bachmeier, K. L., Williams, A. E., Warmington, J. R., and Bang, S. S.: Urease activity in microbiologically-induced calcite precipitation, J. Biotechnol., 93, 171-181, 2002.

Bemis, B. E., Spero, H. J., Bijma, J., and Lea, D. W.: Reevaluation of the oxygen isotopic composition of planktonic foraminifera: Experimental results and revised paleotemperature equations, Paleoceanography, 13, 150-160, 1998.

Bernhard, J. M., Blanks, J. K., Hintz, C. J., and Chandler, G. T.: Use of the fluorescent calcite marker calcein to label foraminiferal test, J. Foramin. Res., 34, 96-101, 2004.

Boyle, E. A.: Cadmium, zinc, and barium in foraminifera tests, Earth Planet. Sc. Lett., 53, 11-35, 1981.

Boyle, E. A.: Cadmium: Chemical tracer of deep water paleoceanography, Paleoceanography, 3, 471-489, 1988.

Boyle, E. A. and Keigwin, L. D.: Comparison of Atlantic and Pacific paleochemical records for the last 215,000 years: Changes in deep ocean circulation and chemical inventories, Earth Planet. Sc. Lett., 76, 135-150, 1985/1986. 
Bradshaw, J. S.: Laboratory studies of the growth rate of the foraminifera "Streblus beccarii (Linné) var. tepida (Cushman)", J. Paleontol., 31, 1138-1147, 1957.

Bruland, K. W. and Lohan, M. C.: Controls of trace metals in seawater, in: The Oceans and Marine Geochemistry, Treatise on geochemistry volume 6, edited by: Elderfield, H., Holland, H. D., and Turekian, K. K., Elsevier, Amsterdam, Heidelberg, 2347, 2004.

Bruland, K. W., Donat, J. R., and Hutchins, D. A.: Interactive influences of bioactive trace metals on biological production in oceanic waters, Limnol. Oceanogr., 36, 1555-1577, 1991.

Buzas-Stephens, P. and Buzas, M. A.: Population dynamics and dissolution of foraminifera in Nueces Bay, Texas, J. Foramin. Res., 35, 248-258, 2005.

Carnahan, E. A., Hoare, A. M., Hallock, P., Lidz, B. H., and Reich, C. D.: Distribution of heavy metals and foraminiferal assemblages in sediments of Biscayne Bay, Florida, USA, J. Coastal Res., 24, 159-169, 2008.

Croteau, M.-N. and Luoma, S. N.: Predicting dietborne metal toxicity from metal influxes, Environ. Sci. Technol., 43, 4915-4921, 2009.

Delaney, M. L., Bé, A. W. H., and Boyle, E.: Li, Sr, Mg, and Na in foraminiferal calcite shells from laboratory culture, sediment traps, and sediment cores, Geochim. Cosmochim. Ac., 49, 1327$1341,1985$.

de Nooijer, L. J., Langer, G., Nehrke, G., and Bijma, J.: Physiological controls on seawater uptake and calcification in the benthic foraminifer Ammonia tepida, Biogeosciences, 6, 26692675, doi:10.5194/bg-6-2669-2009, 2009.

de Nooijer, L. J., Reichart, G. J., Dueñas-Bohórquez, A., Wolthers, M., Ernst, S. R., Mason, P. R. D., and van der Zwaan, G. J.: Copper incorporation in foraminiferal calcite: results from culturing experiments, Biogeosciences, 4, 493-504, doi:10.5194/bg-4493-2007, 2007.

Dissard, D., Nehrke, G., Reichart, G.-J., Nouet, J., and Bijma, J.: Effect of the fluorescent indicator calcein on $\mathrm{Mg}$ and $\mathrm{Sr}$ incorporation into foraminiferal calcite, Geochem. Geophy. Geosy., 10, 2009GC002417, doi:10.1029/2009GC002417, 2009.

Dissard, D., Nehrke, G., Reichart, G. J., and Bijma, J.: Impact of seawater $p \mathrm{CO} 2$ on calcification and $\mathrm{Mg} / \mathrm{Ca}$ and $\mathrm{Sr} / \mathrm{Ca}$ ratios in benthic foraminifera calcite: results from culturing experiments with Ammonia tepida, Biogeosciences, 7, 81-93, doi:10.5194/bg-7-81-2010, 2010a.

Dissard, D., Nehrke, G., Reichart, G.-J., and Bijma, J.: The impact of salinity on the $\mathrm{Mg} / \mathrm{Ca}$ and $\mathrm{Sr} / \mathrm{Ca}$ ratio in the benthic foraminifera Ammonia tepida: Results from culture experiments, Geochim. Cosmochim. Ac., 74, 928-940, 2010 b.

Dueñas-Bohórquez, A., da Rocha, R. E., Kuroyanagi, A., Bijma, J., and Reichart, G.-J.: Effect of salinity and seawater calcite saturation state on $\mathrm{Mg}$ and $\mathrm{Sr}$ incorporation in cultured planktonic foraminifera, Mar. Micropaleontol., 73, 178-189, 2009.

Dyhrman, S. T. and Anderson, D. M.: Urease activity in cultures and field populations of the toxic dinoflagellate Alexandrium, Limnol. Oceanogr., 48, 647-655, 2003.

Egleston, E. S. and Morel, F. M. M.: Nickel limitation and zinc toxicity in a urea-grown diatom, Limnol. Oceanogr., 53, 24622471, 2008.
Erez, J.: The source of ions for biomineralization in foraminifera and their implications for paleoceanographic proxies, in: Biomineralization, edited by: Dove, P. M., de Yoreo, J. J., and Weiner, S., Reviews in Mineralogy and Geochemistry, volume 54, Mineralogical Society of America, Washington, DC, 115-149, 2003.

German, C. R. and von Damm, K. L.: Hydrothermal processes, in: The Oceans and Marine Geochemistry, Treatise on geochemistry volume 6, edited by: Elderfield, H., Holland, H. D., and Turekian, K. K., Elsevier, Amsterdam, Heidelberg, 181-222, 2004.

Hastings, D. W., Emerson, S. R., Erez, J., and Nelson, B. K.: Vanadium in foraminiferal calcite: Evaluation of a method to determine paleo-seawater vanadium concentrations, Geochim. Cosmochim. Ac., 60, 3701-3715, 1996.

Havach, S. M., Chandler, G. T., Wilson-Finelli, A., and Shaw, T. J.: Experimental determination of trace element partition coefficients in cultured benthic foraminifera, Geochim. Cosmochim. Ac., 65, 1277-1283, 2001.

Heiser, U., Neumann, T., Scholten, J., and Stüben, D.: Recycling of manganese from anoxic sediments in stagnant basins by seawater inflow: A study of surface sediments from the Gotland Basin, Baltic Sea, Mar. Geol., 177, 151-166, 2001.

Hemleben, C., Bé, A. W. H., Anderson, R., and Tuntivate, S.: Test morphology, organic layers and chamber formation of the planktonic foraminifer Globorotalia menardii (d'Orbigny), J. Foramin. Res., 7, 1-25, 1977.

Hintz, C. J., Shaw, T. J., Chandler, G. T., Bernhard, J. M., McCorkle, D. C., and Blanks, J. K.: Trace/minor element:calcium ratios in cultured benthic foraminifera, Part I: Inter-species and inter-individual variability, Geochim. Cosmochim. Ac., 70, 1952-1963, 2006.

Hintz, C. J., Chandler, G. T., Bernhard, J. M., McCorkle, D. C., Havach, S. M., Blanks, J. K., and Shaw, T. J.: A physicochemically constrained seawater culturing system for production of benthic foraminifera, Limnol. Oceanogr.-Meth., 2, 160-170, 2004.

Hoaglin, D. C., Mosteller, F., and Tuckey, P. A.: Understanding Robust and Exploratory Data Analysis, John Wiley \& Sons, New York, 1-447, 1983.

Howarth, R. J.: Statistics and data analysis in geochemical prospecting, in: Handbook of Geochemical exploration, edited by: Govett, G. J. S., Volume 2, Elsevier, Amsterdam, 1-437, 1983.

Hunt, J. W., Anderson, B. S., Phillips, B. M., Tjeerdema, R. S., Puckett, H. M., Stephenson, M., Tucker, D. W., and Watson, D.: Acute and chronic toxicity of nickel to marine organisms: Implications for water quality criteria, Environ. Toxicol. Chem., 21, 2423-2430, 2002.

Jochum, K. P., Dingwell, D. B., Rocholl, A., Stoll, B., Hofmann, A. W., Becker, S., Besmehn, A., Bessette, D., Dietze, H.-J., Dulski, P., Erzinger, J., Hellebrand, E., Hoppe, P., Horn, I., Janssens, K., Jenner, G. A., Klein, M., McDonough, W. F., Maetz, M., Mezger, K., Münker, C., Nikogosian, I. K., Pickhardt, C., Raczek, I., Rhede, D., Seufert, H. M., Simakin, S. G., Sobolev, A. V., Spettel, B., Straub, S., Vincze, L., Wallianos, A., Weckwerth, G., Weyer, S., Wolf, D., and Zimmer, M.: The preparation and preliminary characterisation of eight geological MPI-DING reference glasses for in-site microanalysis, Geostandard Newslett., 24, 87-133, 2000. 
Jones, C. J. and Murray, J. W.: Nickel, cadmium, and copper in the northeast Pacific off the coast of Washington, Limnol. Oceanogr., 29, 711-720, 1984.

Kramar, U., Munsel, D., Berner, Z., Bijma, J., and Nehrke, G.: Determination of trace element incorporation into tests of in vitro grown foraminifera by micro-SYXRF - a basis for the development of paleoproxies, in: X-Ray Optics and Microanalysis, edited by: Denecke, M. A. and Walker, C. T., American Institute of Physics Conference Proceedings 1221, ICXOM20, New York, 154-159, 2010.

le Cadre, V. and Debenay, J.-P.: Morphological and cytological responses of Ammonia (foraminifera) to copper contamination: Implication for the use of foraminifera as bioindicators of pollution, Environ. Pollut., 143, 304-317, 2006.

Lea, D. W.: Elemental and isotopic proxies of past ocean temperatures, in: The Oceans and Marine Geochemistry, Treatise on geochemistry volume 6, edited by: Elderfield, H., Holland, H. D., and Turekian, K. K., Elsevier, Amsterdam, Heidelberg, 365390, 2004.

Lea, D. W. and Boyle, E. A.: Ba in planktonic foraminifera, Geochim. Cosmochim. Ac., 55, 3321-3331, 1991.

Lea, D. W. and Spero, H. J.: Experimental determination of barium uptake in shells of planktonic foraminifera Orbulina universa at $22^{\circ} \mathrm{C}$, Geochim. Cosmochim. Ac., 56, 2673-2680, 1992.

Lea, D. W. and Spero, H. J.: Assessing the reliability of paleochemical tracers: Barium uptake in the shells of planktonic foraminifera, Paleoceanography, 9, 445-452, 1994.

Lea, D. W., Mashiotta, T. A., and Spero, H. J.: Controls on magnesium and strontium uptake in planktonic foraminifera determined by live culturing, Geochim. Cosmochim. Ac., 63, 2369-2379, 1999.

Lu, Y. F. and Allen, H. E.: Characterization of copper complexation with natural dissolved organic matter (DOM) - link to acidic moieties of DOM and competition by $\mathrm{Ca}$ and $\mathrm{Mg}$, Water Res., 36, 5083-5101, 2002.

Mann, E. L., Ahlgren, N., Moffett, J. W., and Chisholm, S. W.: Copper toxicity and cyanobacteria ecology in the Sargasso Sea, Limnol. Oceanogr., 47, 976-988, 2002.

Maréchal-Abram, N., Debenay, J.-P., Kitazato, H., and Wada, H.: Cadmium partition coefficients of cultured benthic foraminifera Ammonia beccarii, Geochem. J., 38, 271-283, 2004.

Martin, P. A. and Lea, D. W.: Comparison of water mass changes in the deep tropical Atlantic derived from $\mathrm{Cd} / \mathrm{Ca}$ and carbon isotope records: Implications for changing Ba composition of deep Atlantic water masses, Paleoceanography, 13, 572-585, 1998.

Martin, P. A. and Lea, D. W.: A simple evaluation of cleaning procedures on fossil benthic foraminiferal $\mathrm{Mg} / \mathrm{Ca}$, Geochem. Geophys. Geosy. 3, 2001GC000280, doi:10.1029/2001GC000280, 2002.

Mashiotta, T. A., Lea, D. W., and Spero, H. J.: Experimental determination of cadmium uptake in shells of planktonic foraminifera Orbulina universa and Globigerina bulloides: Implications for surface water paleoreconstructions, Geochim. Cosmochim. Ac., 61, 4053-4065, 1997.

Mashiotta, T. A., Lea, D. W., and Spero, H. J.: Glacial-interglacial changes in Subantarctic sea surface temperature and $\delta^{18} \mathrm{O}$-water using foraminiferal Mg, Earth Planet. Sc. Lett., 170, 417-432, 1999.

Mason, P. R. D. and Kraan, W. J.: Attenuation of spectral inter- ferences during laser ablation inductively coupled plasma mass spectroscopy (LA-ICP-MS) using an rf only collision and reaction cell, J. Anal. Atom. Spectrom., 17, 858-867, 2002.

Middelburg, J. J. and de Lange, G. J.: Particulate manganese and iron framboids in Kau Bay, Halmahera (eastern Indonesia), Mar. Chem., 23, 353-364, 1988.

Morel, F. M. M., Milligan, A. J., and Saito, M. A.: Marine bioinorganic chemistry: The role of trace metals in the oceanic cycles of major nutrients, in: The Oceans and Marine Geochemistry, Treatise on geochemistry volume 6, edited by: Elderfield, H., Holland, H. D., and Turekian, K. K., Elsevier, Amsterdam, Heidelberg, 113-143, 2004.

Morford, J. L. and Emerson, S.: The geochemistry of redox sensitive trace metals in sediments, Geochim. Cosmochim. Ac., 63, 1735-1750, 1999.

Nägler, T. F., Eisenhauer, A., Müller, A., Hemleben, C., and Kramers, J.: The $\delta^{44}$ Ca-temperature calibration on fossil and cultured Globigerinoides sacculifer: New tool for reconstruction of past sea surface temperatures, Geochem. Geophy. Geosy., 1, 2000GC000091, doi:10.1029/2000GC000091, 2000.

Nelson, A. and Donkin, P.: Processes of bioaccumulation: The importance of chemical speciation, Mar. Pollut. Bull., 16, 164-169, 1985.

Nürnberg, D., Bijma, J., and Hemleben, C.: Assessing the reliability of magnesium in foraminiferal calcite as a proxy for water mass temperatures, Geochim. Cosmochim. Ac., 60, 803-814, 1996.

Oliveira, L. and Anita, N. J.: Some observations on the ureadegrading enzyme of the diatom Cyclotella cryptica and the role of nickel in its production, J. Plankton Res., 8, 235-242, 1986.

Pak, D. K., Lea, D. W., and Kennett, J.P.: Seasonal and interannual variation in Santa Barbara Basin water temperatures observed in sediment trap foraminiferal $\mathrm{Mg} / \mathrm{Ca}$, Geochem. Geophy. Geosy., 5, 2004GC000760, doi: 10.1029/2004GC000760, 2004.

Panieri, G.: The effect of shallow marine hydrothermal vent activity on benthic foraminifera (Aeolian Arc, Tyrrhenian Sea), J. Foramin. Res., 36, 3-14, 2006.

Pascual, A., Rodriguez-Lazaro, J., Weber, O., and Jouanneau, J. M.: Late Holocene pollution in the Gernika estuary (southern Bay of Biscay) evidenced by study of foraminifera and ostracoda, Hydrobiologia, 475, 477-491, 2002.

Pearce, N. J. G., Perkins, W. T., Westgate, J. A., Gorton, M. P., Jackson, S. E., Neal, C. R., and Chernery, S. P.: A compilation of new and published major and trace element data for NIST SRM 610 and NIST SRM 612 glass reference materials, Geostandard Newslett., 21, 115-144, 1997.

Reichart, G.-J., Jorissen, F., Anschutz, P., and Mason, P. R. D.: Single foraminiferal test chemistry records in the marine environment, Geology, 31, 355-358, 2003.

Rickaby, R. E. M. and Elderfield, H.: Planktonic foraminiferal $\mathrm{Cd} / \mathrm{Ca}$ : Paleonutrients or paleotemperature?, Paleoceanography, 14, 293-323, 1999.

Russell, A. D., Emerson, S., Nelson, B. K., Erez, J., and Lea, D. W.: Uranium in foraminiferal calcite as a recorder of seawater uranium concentrations, Geochim. Cosmochim. Ac., 58, 671681, 1994.

Sanyal, A., Bijma, J., Spero, H., and Lea, D. W.: Empirical relationship between $\mathrm{pH}$ and the boron isotope isotopic composition of Globigerinoides sacculifer: Implications for the boron isotope pleo-pH proxy, Paleoceanography, 16, 515-519, 2001. 
Solé, V. A., Papillon, E., Cotte, M., Walter, P., and Susini, J.: A multiplatform code for the analysis of energy-dispersive X-ray fluorescence spectra, Spectrochim. Acta B, 62, 63-68, 2007.

Stouff, V., Lesourd, M., and Debenay, J.-P.: Laboratory observations on asexual reproduction (schizogony) and ontogeny of Ammonia tepida with comments on the life cycle, J. Foramin. Res., 29, 75-84, 1999.

Sunda, W. G.: Trace metal interactions with marine phytoplankton, Biol. Oceanogr., 6, 411-442, 1988-1989.

Sunda, W. G. and Huntsman, S. A.: Effect of competitive interactions between manganese and copper on cellular manganese and growth in estuarine and oceanic species of the diatom Thalassiosira, Limnol. Oceanogr., 28, 924-934, 1983.

Sunda, W. G. and Huntsman, S. A.: Antagonisms between cadmium and zinc toxicity and manganese limitation in a coastal diatom, Limnol. Oceanogr., 41, 373-387, 1996.

Sunda, W. G. and Huntsman, S. A.: Processes regulating cellular metal accumulation and physiological effects: Phytoplankton as model systems, Sci. Total Environ., 219, 165-181, 1998a.

Sunda, W. G. and Huntsman, S. A.: Interactions among $\mathrm{Cu}^{2+}$, $\mathrm{Zn}^{2+}$, an $\mathrm{Mn}^{2+}$ in contolling cellular $\mathrm{Mn}, \mathrm{Zn}$, and growth rate in the coastal alga Chlamydomonas, Limnol. Oceanogr., 43, 1055$1064,1998 b$.
Syrett, P. J. and Peplinska, A. M.: The effect of nickel and nitrogen deprivation on the metabolism of urea by the diatom Phaedactylum tricornutum, Eur. J. Phycol., 23, 387-390, 1988.

Urey, H. C.: The thermodynamic properties of isotopic substances, J. Chem. Soc., 562-581, doi:10.1039/JR9470000562, 1947.

Vilela, C. G., Batista, D. S., Bapista-Neto, J. A., Crapez, M., and McAllister, J. J.: Benthic foraminifera distribution in high polluted sediments from Niterói Harbor (Guanabara Bay), Rio de Janeiro, Brazil, An. Acad. Bras. Ciênc., 76, 161-171, 2004.

Wefer, G., Berger, W. H., Bijma, J., and Fischer, G.: Clues to ocean history: A brief overview of proxies, in: Use of proxies in paleoceanography, edited by: Fischer, G. and Wefer, G., Springer, Berlin, Heidelberg, New York, Barcelona, Hong Kong, London, Milan, Paris, Singapore, Tokyo, 1-68, 1999.

Yanko, V., Ahmad, M., and Kaminski, M.: Morphological deformities of benthic foraminiferal tests in response to pollution by heavy metals: Implications for pollution monitoring, J. Foramin. Res., 28, 177-200, 1998.

Yu, J., Elderfield, H., and Hönisch, B.: B/Ca in planktonic foraminifera as a proxy for surface seawater $\mathrm{pH}$, Paleoceanography, 22, PA2202, doi: 10.1029/2006PA00134, 2007.

Zhou, D.: Robust statistics and geochemical data analysis, Math. Geol., 19, 207-218, 1987. 